\title{
Export Tax Reform and the Competitiveness of Imported Soybeans in China - CORRIGENDUM
}

Andrew Muhammad and Constanza Valdes

In the original publication of this article, the corresponding author's email address contained a typographic error. The correct email address for this article's corresponding author, Andrew Muhammad, is amuhammad@utk.edu.

The original article has been corrected. The authors regret this error.

\section{Reference}

Muhammad, A., and C. Valdes. "Export Tax Reform and the Competitiveness of Imported Soybeans in China." Journal of Agricultural and Applied Economics. doi: https://doi.org/10.1017/aae.2019.15

Cite this article: Muhammad A and Valdes C (2019). Export Tax Reform and the Competitiveness of Imported Soybeans in China - CORRIGENDUM. Journal of Agricultural and Applied Economics 51, 526-526. https://doi.org/10.1017/aae.2019.24

(C) The Author(s) 2019. This is an Open Access article, distributed under the terms of the Creative Commons Attribution licence (http:// creativecommons.org/licenses/by/4.0/), which permits unrestricted re-use, distribution, and reproduction in any medium, provided the original work is properly cited. 